\title{
The effect of remittance and volatility in remittances on macroeconomic performance in Africa: any lessons for COVID-19?
}

\author{
Segun Subair Awode ${ }^{1,2}$ (D) Emeka Okoro Akpa $a^{1,3}$ (D) Andy Titus Okwu
}

Received: 29 March 2021 / Accepted: 23 August 2021 / Published online: 27 September 2021

(c) The Author(s), under exclusive licence to Springer Nature Switzerland AG 2021

\begin{abstract}
Premised on the World Bank's projection of a $20 \%$ fall in global remittances due to the effect of the COVID-19 pandemic, there have been concerns that remittancedependent countries may be excessively affected. In this study, we explore the link between remittance, remittance volatility and macroeconomic performance to make a case for the potential impact of the COVID-19 pandemic. Specifically, the study examined the impact of remittance volatility on some macroeconomic variables [real gross domestic product (RGDP), consumption, investment, export and exchange rate] in a panel of seven African countries with the highest remittance-GDP ratio. This was done within a fixed effects and random effects model, using annual secondary data from 2004 to 2018 . Our results show that remittance volatility exerts a negative but insignificant impact on RGDP, consumption, investment, export and exchange rate; while remittances itself has positive significant impact on RGDP, consumption and investment. Based on these findings, while any COVID-19-induced volatility in remittances flow into Africa may yield negative macroeconomic consequences, it is not likely to significantly affect the macroeconomic fundamentals of the most remittance-dependent African countries due to strong kinsmanship and the altruistic nature of remitting African migrants.
\end{abstract}

Segun Subair Awode

awodesegun@gmail.com; ss.awode@niser.gov.ng

Emeka Okoro Akpa

akpaemeka@gmail.com

Andy Titus Okwu

okwua@babcock.edu.ng

1 Department of Economics, Olabisi Onabanjo University, P.M.B 2002, Ago-Iwoye, Ogun State, Nigeria

2 Economic and Business Policy Department, Nigerian Institute of Social and Economic Research (NISER), Ibadan, Nigeria

3 Centre for Econometrics and Allied Research, University of Ibadan, Ibadan, Nigeria

4 Department of Economics, Babcock University, Ilishan, Nigeria 
Keywords Remittances $\cdot$ Remittance volatility $\cdot$ Macroeconomy $\cdot$ COVID-19

JEL Classification F24 · F62 · J61

\section{Introduction}

Remittances have become a vital source of development finance to developing countries (Jha et al. 2010), acting as compensatory transfers in bridging resource deficit gap for households, especially in low- and middle-income countries. It represents a major source of income for poor and vulnerable families in both developed and developing countries. According to the World Bank, remittances enable households with the ability to meet basic needs of life such as food, shelter and healthcare. This notion has gained empirical support as studies have also shown that remittances reduce poverty and inequality in low- and middle-income countries (Akobeng 2015; Bang et al. 2016), boosts nutritional outcomes through its positive impact on private consumption (Akpa 2018; Adelowokan et al. 2020), improves human capital development, thereby reducing child labour and trafficking in disadvantaged communities (Amakom et al. 2014; Amega 2018).

Owing to the global economic crisis occasioned by the COVID-19 pandemic, a potential negative shock to remittances looks inevitable, with crucial implications for vulnerable households as well as developing countries for which remittances represents a significant share of gross domestic product (GDP). The World Bank (World Bank 2020) has projected a decline in global remittances by $20 \%$ in 2020 , said to be the largest decline in recent time, due to the economic crisis caused by the pandemic. ${ }^{1}$ In particular, low- and middle-income countries are projected to experience a $19.7 \%$ decline (from $\$ 48$ billion in 2019 to $\$ 37$ billion in 2020) in remittances, $23.1 \%$ in sub-Saharan Africa, owing to fall in wages and employment of workers in host countries, with some of the top-remittance source markets for the region being in Europe, Middle East, China and US, which were among the places badly hit by the pandemic. Since remittances inflow forms an important source of income for vulnerable households, funding food consumption, education, health and entrepreneurial activities, etc., a decline in remittances flow will affect consumption, expenditure and welfare in remittance-receiving households, which could lead to increased poverty.

However, as the scourge of the pandemic continues to ravage economies and in line with the standard measures taken to curb the spread of the virus, a volatile remittances flow to recipient countries can be expected, dependent on the length of lockdowns in remittances source countries. Despite these projections, the outlook for remittances remains unclear just as the impact of the COVID-19 pandemic on global economies.

\footnotetext{
1 https://www.worldbank.org/en/news/press-release/2020/04/22/world-bank-predicts-sharpest-declineof-remittances-in-recent-history
} 
Although capital flows such as foreign direct investment (FDI) and debt flows are procyclical in nature (Kaminsky et al. 2005; Contessi et al. 2013; Islamaj 2014), World Bank (2015) observed that remittances are acyclical in most countries and countercyclical in others. Remittances are also found to be uncorrelated with other capital inflows, less volatile and less associated with economic fundamentals than other capital inflows (World Bank 2015). Impliedly, while other capital inflows can cause output fluctuations and engender volatile consumption patterns in developing countries, remittances inflows are more stable source of finance with the potential to stabilise balance of payments, support consumption and by extension, the aggregate economy, in the face of capital inflows decline and economic adversity. Additionally, Chami et al. (2005) observed a countercyclical behaviour of remittances, rising in bad times in recipient countries, indicating migrant workers' increased support to families back home in cushioning the effects of busts. However, the economicravaging effects of the COVID-19 pandemic are universal, exerting significant influences on global economies, including remittance source countries.

Although Africa has witnessed the least number of reported confirmed cases which defies expectations, the economic impact of the COVID-19 pandemic on the continent has been severe. The continent witnessed its worst economic recession in half a century, with real GDP contraction of $2.1 \%$ in 2020. Sub-Saharan Africa's economy was also plunged into its first recession in over 25 years, with economic activity contracting by almost $5 \%$ on per capita basis. According to World Bank $(2021)^{2}$ remittances to sub-Saharan Africa which declined by a meagre $0.5 \%$ to $\$ 48$ billion in 2019 , fell by $12.5 \%$ in 2020 to $\$ 42$ billion. The lockdowns and social distancing approaches of containing the spread of the virus would have dealt a blow on remittances flows to SSA as the region remains the most expensive to send money to.

To account for how the shock to remittances flow, occasioned by COVID-19, may affect economies of remittance-dependent countries in Africa, we study the relationship between remittance volatility and key macroeconomic variables, with a view to draw inferences for the impact of COVID-19. The study is a significant contribution to the literature as extant studies have often focused on how remittances inflows affect micro- and macroeconomic variables, with little consideration for volatility in remittances. In analysing the impacts of remittances, a strategy that focuses only on remittances flows is narrow in scope and could completely miss out on a broader understanding of the subject matter (Amuedo-Dorantes and Pozo 2012). It is in light of the foregoing that this study investigates the relationship between remittances volatility and macroeconomic variables in selected African countries through the lenses of the COVID-19 pandemic to understand how the shock to remittances as a result of the virus might affect economies of remittance-dependent countries in the region.

Having introduced the study, subsequently, we review the literature on the subject matter in the second section, the methodological approach to the study was

\footnotetext{
2 https://www.worldbank.org/en/news/press-release/2021/05/12/defying-predictions-remittance-flowsremain-strong-during-covid-19-crisis
} 
presented in section three, and section four presents and discusses the results, while conclusion is drawn in section five.

\section{Literature review}

Remittances flow has been a topical area of research agenda in the economic literature as it has attracted lots of interest from scholars. This could be due to the fact that remittances form important part of foreign capital flows and gross domestic product (GDP) for many developing countries, especially in Africa. As a result, the economic literature is filled with empirical studies that have dealt with diverse issues on remittance flows to Africa (and indeed, other regions). Studies have thus established that, among others, remittances reduce poverty and inequality (Ghosh 2006; Koechlin and Leon 2007; Anyanwu and Erhijakpor 2010; Ratha 2011; Akobeng 2015; Bang et al. 2016), aid human capital development through its positive effect on education and health outcomes (Lu and Treiman 2007, Mohapatra and Ratha 2011; Zhunio et al. 2012; Amakom and Iheoha 2014; Amega 2018) and positively impact on private consumption in recipient countries (Akpa 2018; Adelowokan et al. 2020). The impact of remittance inflows on financial development, economic growth, investment, fiscal and monetary variables have also been investigated in a wider economic literature. However, while the remittances literature is replete, only a few studies have focused on volatility in remittances.

In Mexico, Amudeo-Dorantes and Pozo (2012) examined the effects of remittances volatility on labor force participation of both males and females. The study employed a two-part probit model to analyse data extracted from the ENIGH income and expenditure survey from 2000 to 2008. Results of the study showed that while labor supply (of both male and female) decreases with increase in remittances inflows, an increase in remittance volatility, however, increases the chances of being employed (for male and female) as well as number of hours worked by females who have been hitherto reluctant to join the labor force, suggesting that labor supply responds to fall and rise in remittance inflows in Mexico.

Jackman et al. Craigwell and Moore (2009) analysed the relationship between remittance flows and economic volatility (in recipient countries) in 20 small island developing states (SIDS). The measure of volatility used in the study is a 5-year standard deviation of annual growth rates. The panel fixed-effects model was employed to analyse annual data from 1986 to 2005 and the results showed that remittances stabilise output and investment volatility, implying that a volatile remittances flows can significantly heighten output and investment volatility in SIDS. The study, however, found differential impacts across countries' groupings due to specific peculiarities. The study is similar to that of Craigwell, Jackman and Moore (2009) in objective and methodology. However, Craigwell et al. (2009) focused on a global panel of 95 countries with annual data from 1970 to 2005. The study found no significant effect of remittances on consumption and investment volatility, but noted that it can help lessen the effect of adverse output shocks.

Greenidge and Moore (2011) examined the determinants and volatility of remittance flows in 15 Caribbean countries from 1987 to 2005 using the panel generalized 
least square technique. The study found that remittance flows, significantly determined by interest rate and income differentials between source and recipient countries, domestic inflation, dependency ratio and nominal exchange rate are less volatile than other foreign capital flows despite being higher than FDI flows to the Caribbean.

Jackman (2013) investigated the determinants of remittance volatility in a global panel of 93 countries from 1995 to 2009. As in Jackman et al. (2009), Craigwell et al. (2010), the study used a 5-year rolling standard deviation of growth rates to measure volatility. Employing the panel fixed-effects model, the study found that remittance volatility is significantly determined by altruistic and insurance motives of migrant workers, macroeconomic variables such as exchange rate and inflation, share of skilled migrants and, particularly, economic volatility in the remittance source country.

Jawaid and Raza (2014) examined the effects of remittances and its volatility on economic growth of recipient countries in a sample of five South Asian countries. The study adopted the GARCH approach to measure remittance volatility, while cointegration approach was used to analyse data from 1975 to 2009. Findings showed a positive remittance-growth link in Bangladesh, India, Nepal and Sri Lanka but a negative one in Pakistan. However, remittance volatility is negatively associated with economic growth in Bangladesh, India, Pakistan and Sri Lanka, but positive in Nepal. Overall, less-volatile remittances' flow stimulates economic growth in recipient countries.

Jidoud (2015) examined the transmission channels of the effects of remittances on macroeconomic volatility, specifically output and private consumption volatilities, in a panel of 27 African countries with annual data from 1980 to 2005. The study employed a dynamic stochastic general equilibrium model with financial frictions and found that remittances significantly absorb output shocks, with a smoothing impact on output volatility but have somewhat small impact on consumption volatility.

A closely related study to ours is that of Opperman and Adjasi (2018). However, while we focus on how remittance volatility impacts macroeconomic performance, the study examined the impact of remittance volatility on financial development in a panel of 34 Sub-Saharan African countries between 2002 and 2014. Using the two-step system GMM technique, the study found that negative remittances increase banks' net interest margins and overhead costs, implying a negative impact of remittances on banking sector depth and efficiency. However, the result showed no evidence of the remittances-stock market development nexus.

Owing to the above, it is clear that only a few studies have concentrated on volatility in remittances, implying that an array of issues as it pertains to remittance volatility remain unaddressed in the literature. For countries with high and significant remittance/GDP ratio, fluctuations in the flows could have grave economic consequences. As noted by Chami et al. 2005, remittances are expected to be countercyclically associated with output in recipient countries. This would mean that remittance flows should increase in period of economic turmoil in recipient countries, to act as compensatory transfers. Indeed, Bouoiyour, Selmi and Miftah (2018) did find that remittances have negative effect on economic growth in Tunisia before the 
Arab Spring, but a long run positive impact on growth and consumption post-Arab Spring, influenced by the increased desire of migrant workers to support families rather than by investment motives. However, the same may not be true in a period of global economic slump. In the face of the COVID-19 pandemic that has caused disruptions to economic activities across the globe, there is no denying the effect on global demand with a feedback loop on supply which is crippling incomes even in top-remittance source countries. The attendant effects on income and unemployment in remittance source countries have implications for migrants' capacity to send money home, an indication of shock to remittance flows. It then becomes imperative to investigate how key macroeconomic variables have reacted to volatility in remittance inflows. This would enable us predict the potential macroeconomic performance of these countries as the scourge of the COVID-19 pandemic continues to ravage global economies. The objective of this study therefore is to determine the effect that remittances and volatility in remittances have on macroeconomic performance in countries such as Liberia, Comoros, The Gambia, Lesotho, Senegal, Cabo Verde, Togo, São Tomé and Príncipe, Mali and Guinea-Bissau, where remittances account for significant share of GDP. Beyond filling important gap in the remittances literature, this research agenda has vital implications for policymaking in these countries especially in drawing critical insights in formulating macroeconomic policies to cope with dwindling flow of remittances due to the ravaging effects of the COVID-19 pandemic.

\section{Methodology}

\section{Econometric specification}

This study examines the relationship between remittances, volatility in remittances and macroeconomic variables.

Hypothesis We hypothesize that while increased remittances inflow may have a significant effect on macroeconomic outcomes, the effect on macroeconomic variables of volatility in remittances inflow may be negative but not statistically significant given the strong kinship and altruistic nature of migrants who send remittance into Africa, especially into these economies that have been identified as having remittances inflows as a large share of their GDP. In essence, we do not expect volatility in remittances to significantly affect macroeconomic variables, given the expectation that such volatility will not be strong enough to exert such influence for the reasons earlier highlighted.

We proceed to model the relationship between remittances, remittances volatility and macroeconomic variables. In doing this, we will not treat remittances as capital, given that they represent transfers from the migrants to their recipient households without constraints on how it is spent (Chami et al. 2008). We therefore frame our analysis on endogenously determined remittances as described 
in Chami et al. (2008). That is, we believe that remittances determine macroeconomic variables in the sampled countries, but for remittances to have such effect, it has to be endogenously determined by the strong ties migrants have to home country families and friends, so that volatility in remittances cannot adversely affect macroeconomic fundamentals of the receiving economies.

The econometric specification of the relationship between remittances, remittance volatility and macroeconomic variables in the sampled countries proceeds from Eqs. (1)-(5)

$$
\begin{gathered}
R G D P_{i t}=\beta_{0}+\beta_{1} r e m+\beta_{2} r e m v_{i t}+\beta_{3} \inf _{i t}+\mu_{i t} \\
C O N_{i t}=\beta_{0}+\beta_{1} r e m+\beta_{2} r e m v_{i t}+\beta_{3} i n f_{i t}+\mu_{i t} \\
I N V_{i t}=\beta_{0}+\beta_{1} r e m+\beta_{2} \text { remv }_{i t}+\beta_{3} i n f_{i t}+\mu_{i t} \\
E X P_{i t}=\beta_{0}+\beta_{1} r e m+\beta_{2} \text { remv }_{i t}+\beta_{3} i n f_{i t}+\mu_{i t} \\
E X R_{i t}=\beta_{0}+\beta_{1} r e m+\beta_{2} r e m v_{i t}+\beta_{3} \text { tot }_{i t}+\beta_{4} t o_{i t}+\mu_{i t} .
\end{gathered}
$$

In Eqs. $(1,2,3,4,5)$

$$
\mu_{i t}=\alpha_{i}+\gamma_{i}+\eta_{i}
$$

where

$\alpha_{i}$ is the unobserved cross section specific effect

$\gamma_{i}$ is the unobserved time specific effect

$\eta_{i}$ is the common cross section time series effect (Olubusoye et al. 2016).

In the dependent variables, $R G D P$ denotes real gross domestic product, $C O N$ is household final consumption expenditure, $I N V$ is investment proxied by gross capital formation, EXP denotes export and EXR denotes exchange rate, all for country $i$ at time $t$.

In the independent variables, rem is inward remittances and remv is remittances volatility, while inf denotes inflation, all for country $i$ at time $t$.

$\mu_{i t}$ is error term for country $i$ at time $t$.

We estimated the equations using the fixed effect model for all the equations except for the exchange rate equation which was estimated with the random effect models. The choice of model was determined using the Hausman test.

For the growth, consumption, investment and export equations, the independent variables are remittance volatility, remittances and inflation. Inflation is included as a control variable in the RGDP, consumption, investment and export equations in line with Ayyoub, et al. (2011), Bonsu and Muzindutsi (2017), Hoggar (2015) and Uysal and Mohamoud (2018), respectively. In the exchange rate equation, terms of trade and trade openness were included as control variables in line with Coudert et al. (2008) and Kamenik and Kumhof (2014). 


\section{Data issues}

The study uses annual data on all the variables spanning through the period 2004-2018. Data were sourced from World Bank's World Development Indicators (WDI) on RGDP measured in million constant 2010 US\$, personal remittances (rem) received in million current US\$, gross fixed capital formation as a proxy for investment (INV), measured in million constant 2010 US\$, consumption (CON) (household final consumption expenditure), measured in million constant 2010 US\$, inflation (inf) as change in consumer price index, net barter terms of trade (tot) index, trade openness (to) as the share of a country's export and import in GDP and exchange rate (EXR) as local currency value vis-à-vis the US dollar. We obtain remittance volatility (remv) through the Hodrick-Prescott (1997) (HP) filter to remove the short-term component of cyclicality in remittances. This was done on remittances data from 2004 to 2018 and setting $\lambda$ to 100 given that the data series is annual. All variables (apart from inf and to) are expressed in their natural logarithmic form.

The top ten countries in Africa for which remittances account for a significant portion of their GDP according to World Bank (2016), using 2014 values (that is, remittance-GDP values in 2014), were selected for this study. They are also referred to as high remittance-dependent countries (Massa and te Velde 2008). These countries are Liberia (24.6 percent), Comoros (20.2 percent), The Gambia (20.0 percent), Lesotho (17.4 percent), Senegal (10.3 percent), Cabo Verde (10.2 percent), Togo (8.8 percent), São Tomé and Príncipe (8.0 percent), Mali (7.4 percent), and Guinea-Bissau (6.2 percent). However, due to data paucity for consumption in São Tomé and Príncipe, Cabo Verde and The Gambia, they were dropped from the analysis.

The panel is unbalanced as inflation values for Comoros for 2014 to 2018 were not found, investment and consumption values for Lesotho from 2004 to 2006 and 2017 and 2018, respectively, were also not available, and 2018 inflation figure for Guinea-Bissau was not available.

\section{Results and discussion}

\subsection{Trend analysis of remittances inflows into the selected countries for the study}

The study begins its analysis by assessing the trend behaviour of remittances within the period under study for the selected countries. The result, as presented in Fig. 1, shows that the countries selected largely exhibit similar upward trend in remittances within the period under review. However, it will be observed that there was a noticeable decline in inflows for Togo from 2010 to 2011, Lesotho from 2011 to 2015 and 2015 to 2016 for Guinea-Bissau. Some of these declines in remittance inflows may not be unconnected to the economic conditions of the remittance sending countries, and the use of informal channels to transmit remittances. 

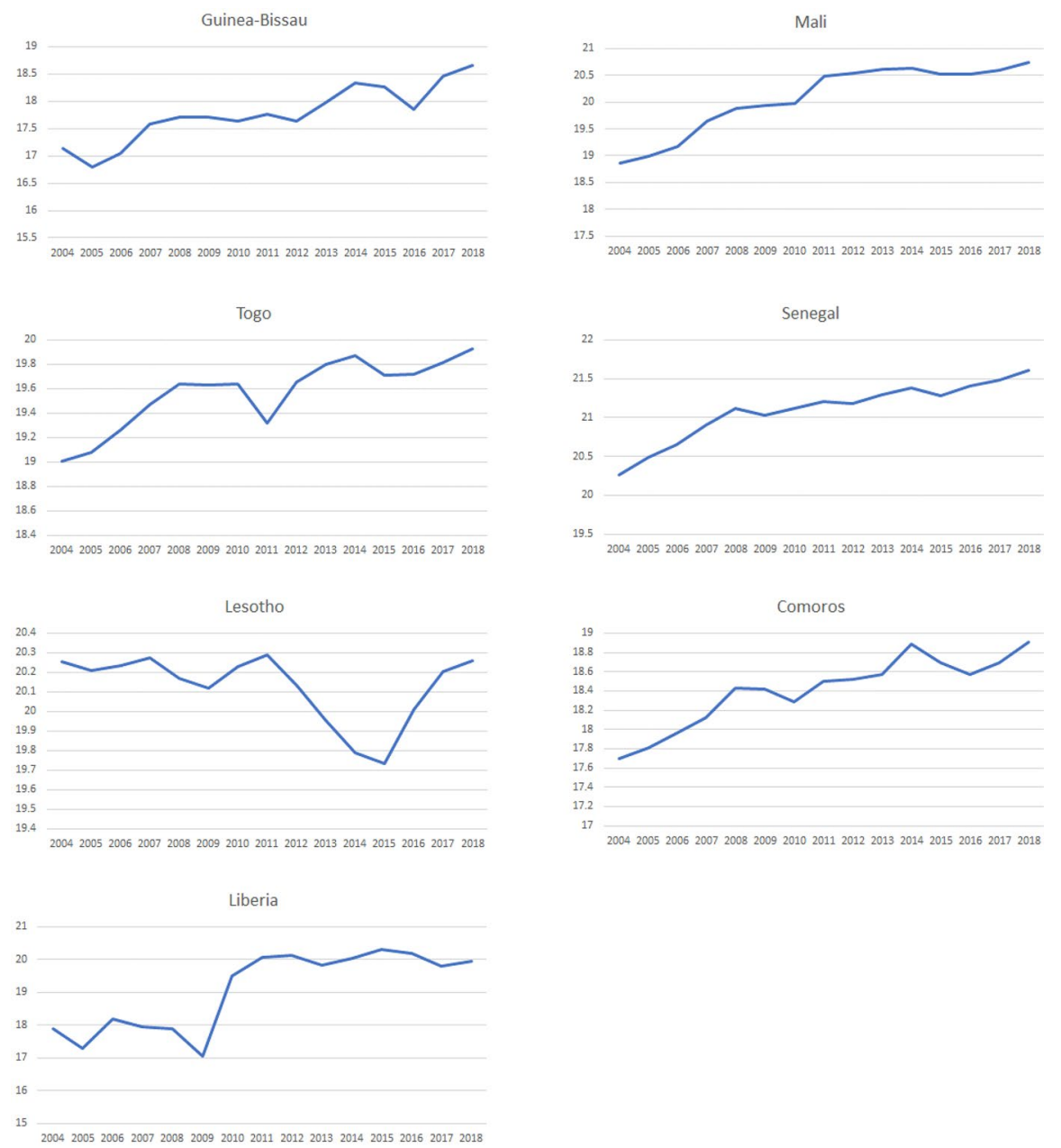

Fig. 1 Trends in inward personal remittances (expressed in natural log forms). Source: Authors' computation 2021

\section{Descriptive analysis}

Table 1 contains the basic statistical summary of each variable in the study. From the table, it is observed that apart from RGDP and inflation, all the other variables are normally distributed as can be observed from the probability values of the Jarque-Bera statistic. Remittance volatility and terms-of-trade are observed to be negatively skewed, while trade openness, RGDP, remittance volatility and inflation present heavier tails than a normal distribution as they are leptokurtic. 


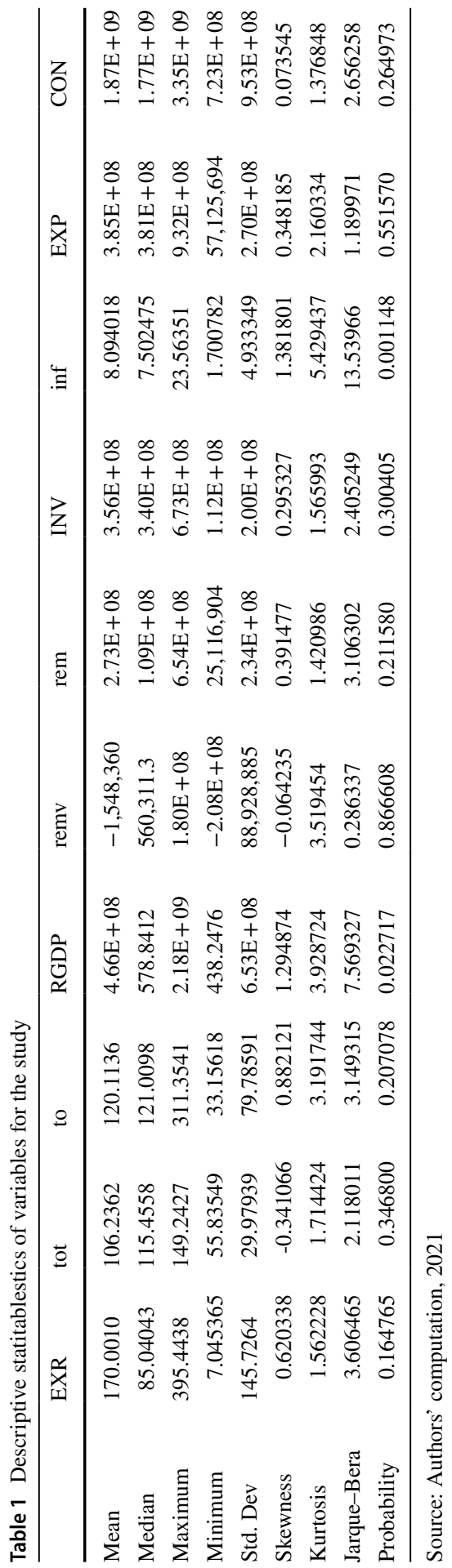


Table 2 Correlation matrix of explanatory variables

\begin{tabular}{lcllll}
\hline & Rem & Remv & Inf & To & Tot \\
\hline Rem & 1.000000 & & & & \\
Remv & 0.726755 & 1.000000 & & & \\
Inf & 0.315027 & 0.345785 & 1.000000 & & \\
To & -0.211027 & 0.053066 & 0.661003 & 1.000000 & \\
Tot & 0.503083 & 0.495340 & 0.765931 & 0.430153 & 1.000000 \\
\hline
\end{tabular}

Source: Authors' computation, 2021

\section{Correlation analysis}

The correlation matrix presented in Table 2 shows that the independent variables in each of the equations do not suffer from multicollinearity. We followed Kim (2019), to draw the threshold at which there could be possible multicollinearity problem, that is if the correlation coefficient $|r|>0.8$

\section{Regression result}

\section{Discussion of findings}

In Table 3, we present the estimated result on the effect of remittance and remittance volatility on macroeconomic performance in selected African countries using the fixed effects and random effects model. The fixed effects and random effects model were compared using the Hausman test which indicated that the fixed effect was the preferred model for the RGDP, consumption, investment and export equations, and the random effects model preferred for the exchange rate equation; thus, our interpretation of results will be based on the selected model.

The result of the fixed effects model showed that the coefficient of remittance volatility across all the equations is in agreement with the hypothesized relationship we had earlier stated. It is observed that remittance volatility exerts a negative effect on both RGDP, consumption, investment, export and exchange rate. From the result, a $1 \%$ rise in remittance volatility will induce about $0.003 \%, 0.03 \%, 0.02 \%, 0.03 \%$ and $0.003 \%$ decline in RGDP, consumption, investment, export and exchange rate, respectively. This relationship is, however, not statistically significant at the 0.05 threshold. On the other hand, remittances itself are found to be positively related to all of the target variables, and statistically significant for RGDP, consumption and investment equations. From the result, a $1 \%$ increase in remittances is likely to exert a corresponding rise in RGDP, consumption and investment $0.16 \%, 0.42 \%$ and $0.50 \%$, respectively.

It is observed that volatile remittances exert negative effect on both domestic and external sectors of the economy. Yet, given that we had earlier hypothesized a nonsignificant effect of remittance volatility on the selected macroeconomic variables due to the strong link remitting migrants have with members of their household in the receiving countries, we find that though volatility in remittances may negatively 


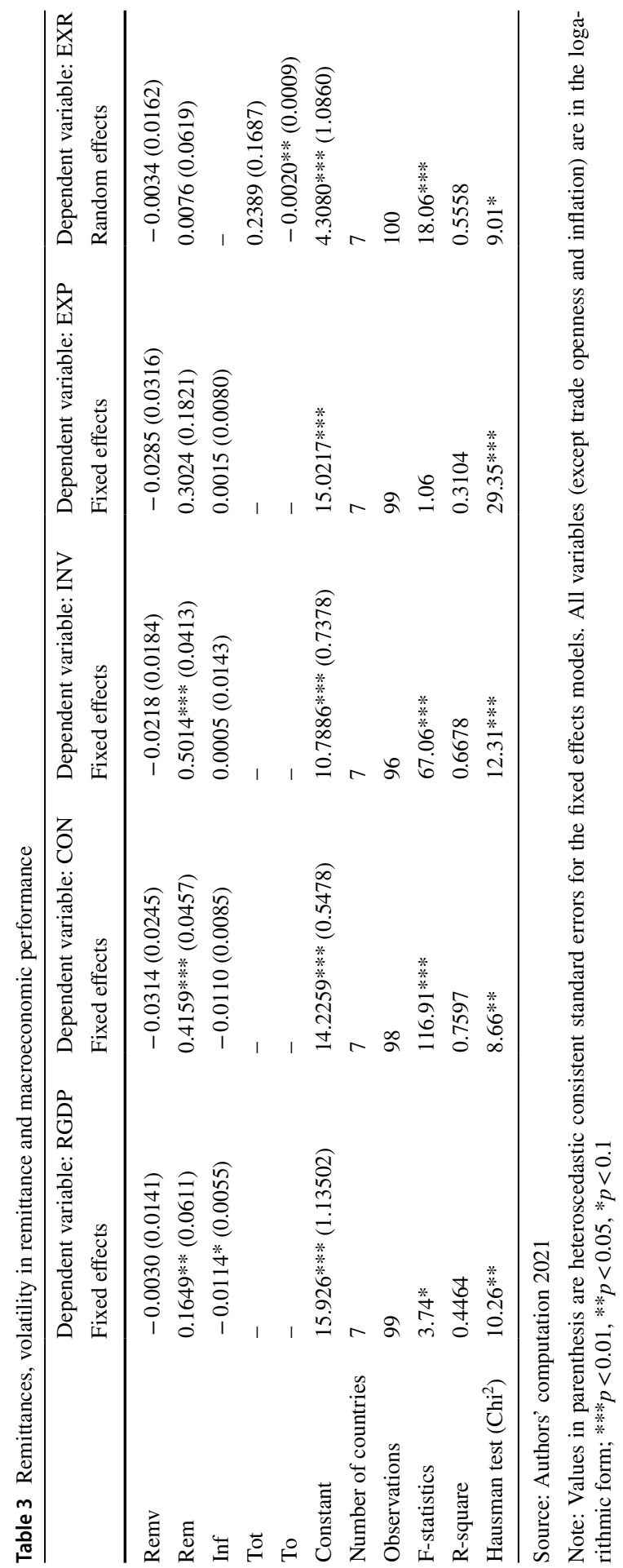


affect the macroeconomy, this effect is not expected to be influential. Thus, a COVID-19-induced volatility in remittances is not expected to cause any significant impact on the macroeconomy of the selected countries in this study.

The positive influence of remittances on consumption is in line with Akpa (2018); Adelowokan et al. (2020). Unlike Akpa (2018) and Adelowokan et al. (2020), this study found a significant relationship between remittances and consumption. This difference in outcome may be the result of selecting countries whose economy is more dependent on remittances in the current study. Furthermore, the significant positive effect of remittances on RGDP, consumption and investment go to show how dependent the domestic economies of the selected countries are on remittances.

\section{Concluding remarks and lessons for COVID-19}

We have considered the effect of remittances and volatile remittances on the macroeconomy in some African countries for whom remittances are economically more significant. For want of data, the countries sampled were reduced from ten to seven, covering a period of 2004-2018. The fixed and random effects estimators were adopted for empirical analysis, and the result of the Hausman test showed preference for the fixed effects model. Results from the analysis show that remittances' volatility exerts negative, but statistically insignificant effect on RGDP, consumption, investment, export and exchange rate, while remittances exert positive effects on RGDP, consumption and investment; an effect that was statistically significant for consumption and investment, at the 5\% level of significance.

The World Bank (2020) had predicted that the COVID-19 pandemic would result in remittances to low- andmiddle-income countries falling by about $20 \%$, from $\$ 554$ billion in 2019 to $\$ 445$ billion in 2020 . Given this projected level of decline in inward remittances, there have been fears that some of the countries in Africa for which remittances represent a major part of national output may be disproportionately affected. This study has validated the notion that for remittances, the macroeconomy of some of the most remittance-dependent countries in Africa prefers certainty over uncertainty. Drawing from this, COVID-19-induced volatility in remittances into Africa may result in negative macroeconomic response howbeit short-lived or without a significant effect, given that the World Bank (World Bank 2020) has predicted a 7.5 recovery in 2021.

The insignificant effect of remittance volatility on the macroeconomy of the selected countries may be explained on the altruistic nature of remitting migrants. With very strong ties to their home countries, to the extent of seeing their home countries as an extension of themselves, migrants who may have suffered setbacks in earnings will still find ways to send money back to their families in their home countries.

In the end, volatility in remittances does not significantly explain macroeconomic changes in the countries selected in Africa. Furthermore, the potential effects of volatility in remittances may be counterbalanced by rising local currencydollar exchange rate due to external shocks that may be caused by the COVID-19 
pandemic. This may increase the unit value of remittance inflows and help economic agents cope with its volatilities.

Author contributions All authors have contributed equally to this work.

Funding No funding was received for this study.

Data availability Data will be available only on reasonable request from the authors.

\section{Declarations}

Conflict of interest The authors declare that they have no conflict of interest.

Ethical approval This article does not contain any studies with human participants or animals performed by any of the authors.

\section{References}

Adelowokan OE, Adesoye AB, Akpa EO, Maku OE (2020) Remittances, foreign aid and private consumption in sub-Saharan Africa (SSA): a system GMM estimation. KIU J Soc Sci 5(4):67-76

Akobeng E (2016) Out of inequality and poverty: evidence for the effectiveness of remittances in SubSaharan Africa. Quart Rev Econ Finance 60:207-223. https://doi.org/10.1016/j.qref.2015.10.008

Akpa EO (2018) Private remittances received and household consumption in Ghana (1980-2016): an ARDL analysis with structural breaks. Internat J Manag Econ Invent 4(5):1771-1777

Amakom U, Iheoma CG (2014) Impact of migrant remittances on health and education outcomes in SubSaharan Africa. IOSR J Hum Soc Sci 19:33-44

Amega K (2018) Remittances, education and health in Sub-Saharan Africa. Cogent Econ Finance 6(1):127. https://doi.org/10.1080/23322039.2018.1516488

Amuedo-Dorantes C, Pozo S (2012) Remittance income volatility and labor supply in mexico. South Econ J 79(2):257-276. https://doi.org/10.4284/0038-4038-2011.102

Anyanwu JC, Erhijakpor AE (2010) Do international remittances affect poverty in Africa? Afr Dev Rev 22:51-91

Ayyoub M, Chaudhry IS, Farooq F (2011) Does inflation affect economic growth? The case of Pakistan. Pak J Soc Sci (PJSS) 31(1):51-64

Bang JT, Mitra A, Wunnava PV (2016) Do remittances improve income inequality? An instrumental variable quantile analysis of the Kenyan case. Econ Model 58:394-402. https://doi.org/10.1016/j.econm od.2016.04.004

Barro RJ (2013) Inflation and economic growth. Ann Econ Financ 14(1):121-144

Bleaney M, Greenway D (2011) The impact of terms of trade and exchange rate and real exchange rate volatility on investment and growth in sub-Saharan Africa. J Dev Econ 65:491-500

Bonsu CO, Muzindutsi PF (2017) Macroeconomic determinants of household consumption expenditure in ghana: a multivariate cointegration approach. Int J Econ Financ Iss 7(4):737-745

Bouoiyour J, Selmi R, Miftah A (2017) The relationship between remittances and macroeconomic variables in times of political and social upheaval: evidence from Tunisia's Arab Spring. Econ Trans Instit Change 27:355-394

Chami R, Fullenkamp C, Jahjah S (2005) Are immigrant remittance flows a source of capital for development? IMF Staff Pap 52(1):55-81

Chami R, Barajas A, Cosimano F, Fullenkamp C, Gapen M, Montiel P (2008) Macroeconomic consequences of remittances. Internat Monetary Fund.

Contessi S, De Pace P, Francis JL (2013) The cyclical properties of disaggregated capital flows. J Int Money Financ 32:528-555

Coudert V, Couharde C, Mignon V (2008) Do terms of trade drive real exchange rates?: Comparing Oil and Commodity Currencies. CEPII. 
Craigwell R, Jackman M, Moore W (2010) Economic volatility and remittances. Internat J Dev Iss 9(1):25-42. https://doi.org/10.1108/14468951011033789

Ghosh B (2006) Migrants' remittances and development: myths, rhetoric and realities. Internat Org Migr.

Greenidge KCD, Moore AR (2011) Determinants and volatility of remittances in the caribbean. SSRN Electron J. https://doi.org/10.2139/ssrn.1337003

Hodrick R, Prescott EC (1997) Postwar US business cycles: an empirical investigation. J Money Credit Bank 29(1):63-75

Hoggar GF (2015) Modelling the inflation-investment Nexus in Ghana. Internat J Phys Appl Sci 2(6): $17-28$

Islamaj E (2014) Industrial specialization, financial integration and international consumption risk sharing. BE J Macroecon 14(1):477-509

Jackman M (2013) Macroeconomic determinants of remittance volatility: an empirical test. Internat Migr. https://doi.org/10.1111/imig.12100

Jackman M, Craigwell R, Moore W (2009) Economic volatility and remittances: evidence from SIDS. J Econ Studies 36(2):135-146. https://doi.org/10.1108/01443580910955024

Jawaid ST, Raza SA (2016) Effects of Workers' remittances and its volatility on economic growth in South Asia. Int Migr 54(2):50-68. https://doi.org/10.1111/imig.12151

Jha S, Sugiyarto G, Vargas-Silva C (2010) The global crisis and the impact on remittances to developing Asia. Glob Econ Rev 39(1):59-82. https://doi.org/10.1080/12265081003696395

Jidoud A (2015) Remittances and macroeconomic volatility in African countries. IMF Working paper no. WP/15/49. Internat Monetary Fund

Kamenik O, Kumhof M (2014) Trade Openness and exchange rate regimes. J Money Credit Bank 46(8):1657-1686

Kaminsky GL, Reinhart CN, Vegh CA (2005) When it rains, it pours: procyclical capital flows and macroeconomic policies. NBER Macroecon Annual.

Kim JH (2019) Multicollinearity and misleading statistical results. Korean J Anaesthesiol 72(6):558-569

Koechlin V, Leon G (2007) International remittances and income inequality: an empirical investigation. J Econ Policy Reform 10(2):123-141

Lu Y, Treiman DJ (2007) The effect of labour migration and remittances on children's education among blacks in South Africa. California Centre for Population Research

Massa I, te Velde DW (2008) The global financial crisis: will successful african countries be affected? Overseas Development Institute (ODI)

Mohapatra S, Ratha D (2011) Migrant remittances in Africa: an overview. The World Bank

Olubusoye EO, Salisu AA, Olofin SO (2016) Applied panel data analysis. Ibadan University Press

Opperman P, Adjasi CKD (2019) Remittance volatility and financial sector development in sub-Saharan African countries. J Policy Model 41(2):336-351. https://doi.org/10.1016/j.jpolmod.2018.11.001

Ratha D (2011) Leveraging migration for Africa: remittances, skills and investments. World Bank Publication

Uysal Ö, Mohamoud AS (2018) Determinants of export performance in East Africa countries. Chinese Business Rev 17(4):168-178

World Bank (2016) Migration and remittances factbook, 3rd edn. International Bank for Reconstruction and Development/The World Bank

World Bank (2015) Global Economic Prospects, June 2015: The Global Economy in Transition.

World Bank (2020) COVID-19 Crisis through a migration lens: migration and development brief 32

Zhunio MC, Vishwasrao S, Chiang EP (2012) The influence of remittances on education and health outcomes: a cross country study. J Appl Econ 44:4605-4616 